\title{
KIT Gene
}

National Cancer Institute

\section{Source}

National Cancer Institute. KIT Gene. NCI Thesaurus. Code C18609.

This gene plays a role in cellular hematopoiesis and differentiations. Mutations in the gene are associated with several diseases, including acute myelogenous leukemia, gastrointestinal tumors, and mast cell disease. 